\title{
ITSEREFLEKTIO JA KOHENTUNUT VOINTI HAASTATTELUPUHEESSA
}

\begin{abstract}
Itsereflektio on oman kokemuksen, toiminnan, tiedon tai asennoitumisen erittelyä. Sitä tarvitaan osana oppimisprosesseja, asiantuntijuutta ja terapeuttista muutosta. Terapisoituva kulttuuri ja useilla elämänalueilla kasvava vaatimus yksilön suorittamaan itsen muokkaamiseen ja itseä koskevien tulkintojen esittämiseen tekee itsereflektiosta tärkeän tutkimuskohteen aikuiskasvatuksen, psykoterapiatutkimuksen sekä sosiologian kannalta.
\end{abstract}

\section{SANNA VEHVILÄINEN \& OLAVI LINDFORS}

$\mathrm{E}$ linikäisen oppimisen idea edellyttää jatkuvaan oppimiseen ja itsen muokkaamiseen kykenevää kansalaista. Jo päiväkodeissa lapsilta edellytetään itsearviointia; kouluoppimisen tutkimuksessa kykyä itsereflektioon ja metaoppimiseen pidetään keskeisenä. Erilaiset arviointikäytänteetkin muuttuvat reflektiota ja diskursiivisuutta edellyttävään suuntaan. Itsereflektion käytänteet ovat jo kansalaistaidon asemassa. "Itse" on projekti, jota tulee osata tarkkailla ja tulkita ja josta on kyettävä keskustelemaan eri tilanteissa.

Useiden sosiologien mukaan aikanamme voidaan puhua elämänmuodosta, johon kuuluu yksilön jatkuva itsen muokkaamisen ja itsen itselle tulkitsemisen projekti. Jälkimodernin yksilön olosuhdetta kuvataan paitsi mahdollisuutena, myös vaatimuksena itsen tarkkailuun ja työstöön (Giddens 1991; Rose, 1999; Glastra ym. 2004, Furedi 2004). Kyse on identiteettityöstä muuttuvissa olosuhteissa. Yksilön psyyke nähdään yhteiskunnallisen vallan tai "hallinnallisuuden" ytimenä (Foucault 2005; Rose 1999; vrt. Cameron 2000, 1-7.) "Terapisoituvassa” yhteiskunnassa yksilöiden psyykejä koskevien tietomuotojen tapojen katsotaan olevan oleellisia laajalti yhteiskunnassa, ei ainoastaan psykoterapian tai psykiatrian piirissä (Rose 1999; vrt. Cameron 2000, 154 161). Nikolas Rosen mukaan yhteiskuntaamme kannattelee laajalti ajatus, että nimenomaan yksi- löpsyykeä koskeva tieto on ratkaisevinta sekä yhteiskunnallisten että yksilöiden ongelmien ratkomisessa. Itsereflektio - pyrkimys tietää itsestä - kytkeytyy siis monin tavoin kansalaisena selviytymisen, hyvinvoinnin ja terveyden kysymyksiin.

Psykologisoituneen elämänmuodon tutkijoiden mielestä yksilöiden on yhteiskunnassamme tavallaan välttämätöntä mieltää elämänsä nimenomaan itsetoteutukseen tähtäävien valintojen tuloksena (Rose 1999, 231; Usher ym. 1997, 93110). Yksilöitä hallinnoidaan - ja he hallinnoivat itseään - elämänprojektiensa ja niitä koskevan itsereflektion kautta (Rose 1999, Giddens 1991). Tähän elämänmuotoon liittyy myöskin yksilön itsetoteutusta tukeva eetos (Taylor 1995; Usher ym. 1997, 113-115). Se tiivistyy humanistisessa psykologiassa (Rogers 1994[1967]), joka esiintyy myös aikuiskasvatustieteellisessä kirjallisuudessa (esim. Baumgartner 2001; Kovan \& Dirkx 2003; Kroth \& Boverie 2000). Tämä eetos tavataan monista kulttuurituotteista kuten itseapukirjallisuudesta, perhelehdistä ja televisio-ohjelmista (Cameron 2000, 149-161).

Yksilöiden harjoittama itseymmärrykseen tähtävä työ on kiinteä osa modernia elämäntapaamme. Ihmisten oletetaan käyttävän itsetoteutusta yhtenä keskeisenä perusteluna elämänvalinnoissa ja elämänongelmien ratkomisessa. Tällaista arvioivan itsetarkkailun prosessia voidaan kut- 
sua itsereflektioksi ja ymmärtää se mielensisäiseksi kyvyksi, muutosvoimaksi. Aikuiskasvatustieteessä tarkastellaan itsereflektiota useimmiten nimenomaan oppimisteoreettisesti (Mezirow 1981; Mezirow ym. 1990; Jarvis 1987; Brookfield 1987; Marsick \& Watkins 1990, 3-34; Schön 1991; Malinen 2000, 55-100; Baumgartner 2001, 15-24). Kriittinen itsereflektio on tällöin oman ajattelun ja kokemistavan perusteita muuttavan oppimisen edellytys.

Tässä artikkelissa esitetään, että itsereflektio on myös sosiaalisesti jäsentyvä puhetapa sekä vuorovaikutuksellinen ilmiö. On monia tilanteita, joissa ihmisten ottavat puheessaan huomioon oletuksen, että "minä" on yksilön projekti, siitä tulee hankkia tietoa ja puhujan tulee osoittaa omaavansa tarkkaileva, evaluoiva ja tulkitseva suhde itseensä.

Näitä puhetapoja - itsereflektion käytäntöjä ja malleja — opitaan kaikkialla arkielämässä, mutta erityisesti koulutuksen ja terapian instituutioiden piirissä. Lisäksi näiden instituutioiden välille asettuvat "itsekehittämismarkkinat”, joissa hyödynnetään sekä terapeuttisia että oppimisen diskursseja. Kyse on nimenomaan vapaista markkinoista: lehdistä, kirjoista, tv-ohjelmista, keskustelupalstoista. Nämä kaikki instituutiot ovat arkipäivän oppimisen näkökulmasta oleellisia, koska ne tarjoavat sisältöjä ja välineitä (ajattelu- ja puhetapoja) yksilöiden itsereflektioon. Toisaalta ne myös ylläpitävät, oikeuttavat ja normalisoivat itsereflektion vaatimusta aikuisen ihmisen kansalaistaitona (Glastra ym. 2004; vrt. Edwards 1994; Usher ym. 1997; Rose 1999; Cameron 2000.

Puhetavat (tai diskurssit) voivat olla kulttuurisia merkityksiä tai repertuaareja. Tällainen diskurssi voisi olla esimerkiksi populaaripsykologinen käsitys "sisäisestä lapsesta”, joka aikuisen tulee oppia tuntemaan ymmärtääkseen itseään. Puhetavoilla voidaan kuitenkin myös tarkoittaa erilaisia kielellisiä keinoja ja vuorovaikutuksen rakenteita. Tässä artikkelissa tarkastellaankin itsereflektiota kielellisenä käytänteenä, jolla on lisäksi vuorovaikutuksessa erityinen käyttötapa. Artikkelissa sovelletaan keskustelunanalyyttistä lähestymistapaa. Itsereflektiolla tarkoitetaan tässä tapaa muotoilla puheenvuoro niin, että puhuja asettuu arvioivaan, tarkkailevaan ja tulkitsevaan suhteeseen itseensä. Toisin kuin välittömän havainnon tai kokemustiedon kuvauksissa, tällainen puhe esittää "itsen" havainnon, tiedonkeruun, päättelyn ja problematisoinnin kohteena.
Artikkelissa tarkastellaan tilannetta, jossa itsereflektiivinen puhe toimii vakuuttavuuden lähteenä: terapiaa käynyt potilas kertoo tutkimushaastattelussa voivansa paremmin. Ollakseen vakuuttava tässä institutionaalisessa kontekstissa potilaan täytyy siis kielellisten käytäntöjen tasolla rakentaa puheeseensa itsereflektiota.

\section{ITSEREFLEKTIO DISKURSIIVISENA KÄYTÄNTÖNÄ}

Seuraavaksi tarkastellaan itsereflektiota keskusteluilmiönä psykoterapiaan liittyvässä kontekstissa. Kysytään, 1) miten itsereflektiivisiä puheenvuoroja muotoillaan ja 2) mitä tehtäviä itsereflektiivinen puhe vuorovaikutuksessa toimittaa. Tällaista tietoa tarjoaa keskustelunanalyysi, joka tarkastelee vuorovaikutuksessa esiintyviä keinoja, toimintoja, niiden sekventiaalista (peräkkäistä t. seuraantoon perustuvaa) muotoutumista ja tutkii, miten institutionaaliset tehtävät tai päämäärät "puhutaan eläviksi” vuorovaikutuksen käytänteissä keskustelussa (esim. Heritage 1997).

Katsotaan ensin itsereflektiivistä puhetta. Ote (esimerkki 1) on peräisin artikkelin aiheena olevasta aineistosta. Siinä naispotilas selostaa vointinsa kohentumisen perusteita haastattelijan pyydettyä häntä tarkentamaan vointikuvaustaan. Potilas kuvaa oppimistaan implikoiden syitä psykoterapiaan hakeutumisen syynä olleille ongelmilleen. (Aineistosta tarkemmin tuonnempana, litteraatiomerkeistä liitteessä 1 . Kaikki erisnimet ja vastaavat tiedot on muutettu.)

Vertailun vuoksi tarkastellaan otetta AA-palaverien vuorovaikutusta käsittelevästä tutkimuksesta (Arminen 1998). Otteen (esimerkki 2) mies esittää kokemuksellisen tarinan suuressa AA-kokouksessa. AA-palavereissa esitetyt elämäkerralliset monologit käsittelevät aina tavalla tai toisella alkoholismia ja siitä toipumista AA:n avulla. 


\section{ESIMERKKI 1 [24KK/PITKÄ PSYKODYNAAMINEN]}

1 PO: $\quad$ mm () no mihin sitä nyt ois tyytyväinen ni ehkähh () ehkä sillee et on oppinu niinku

HA: mhh hyväksymää () niinku itseni (-) niinku sillee virheineen päivinee, 0

PO: tavallaa ei vạadi nii paljo iteltää () ja tavallaa just tse et mmm mistä on niinku pääsemäs huomaa eriksee et ei niin herkästi syyllistä () itseänsä () [niinku yleensäkkää asiois tai tavallaan

HA:

$[\mathrm{mm}$

9 PO: niinku () mmm mitä vois tän kạhen vuoden aikana ni ajatella ni sillä viisii niinku on paljon varmempi et esimerkiks mu- niinku huomaan semmosis et jos mä tüun semmosiin tilanteisiin misson valmiiks ihmisii nii () niihin tillanteisiin on niinku () hüomattavasti helpompi tulla ku joskus aikasemmi et sitä [ei niinku mieti et mitä müut ajattelee

HA: [mmh.

14 PO: tai miten mä tähän tụun et niinku () ne tapahtuu niinku paljo lụontevammin

15

PO: $\quad$ et tsiinä mieles varmaan se () oma îtsetunto on niinkunh () noususs

\section{ESIMERKKI 2 [ARMINEN 1998, 65-66 (VIMARKKU0686)]}

1 Mä muistan muutama v- muutamia vuosi sitten () kun mä tulin tänne, tähän AA-yhteisöön ja, 2 () mul- mä olin hyvin voi yyh voimakkaasti alemmuudentuntoinen ja () tuota yhm () vähättelin 3 itseäni ja () häpesin menneisyyttäni ja () tekojani ja () kaikkia tämmösiä ja. () Mä olin tuolla 4 reissulla ja () huomasin että () mulla on poistunu tämmöst () tämmöset ajatukset () mielestä () 5 aika pitkälti ja. () uuh Huomasin ett mä ehkä saatan et mä oon tervehtynyt hieman tällä alueella. $6 \quad$ () .hhh Mä .hh huomasin että mä oon aivan turhaan väheksyny itseäni, () kun mä katselin sitä 7 joukkoa ympärillä, että mä oon aivan ihan turhaan, () siis yhm m- mää- tää ei tarkota sitä että mä 8 arvostelisin, mut mä uskoisin että mä oon niinku yhh t- jollakin tavalla itse tuota () ruvennu 9 muuttuu, mun vaimoni sanoi tänään että, () hän yhtyy sinuun () et tota sä et oikein luota itsees

Itsereflektio esiintyy tässäkin nimenomaan myönteistä muutosta kuvaavan selonteon piirteenä.

Otteet ilmentävät joitain kulttuurimme perusrakenteita. Puhuja tarkkailee itseään; ymmärrettävämmäksi käyvä, vähittäin paljastuva "minä" on puhujan projekti. Otteissa peilataan muuttunutta itseä ja puhutaan vaikeista tunteista kuten häpeä ja syyllisyys. Käytetään arkikielistyneitä psykologisia termejä (alemmuudentunto, itsetunto, itsen syyllistäminen), kuvataan oppimis- tai kasvukokemusta ja implikoidaan sellainen mielen dynamiikka, jossa subjekti tervehtyy vapautumalla vahingollisista itseä koskevista uskomuksista.

Uutisarvoista ei lienekään tunnistaa otteita terapisoituneen kulttuurin tai itsetoteutuksen eetoksen kantajiksi (vrt. Kivivuori 1991; 1999). Tässä artikkelissa sen sijaan tarkastellaan, miten tällaiset kulttuuripiirteet rakennetaan kielen keinoin keskustelutilanteessa. Kuinka puhuja rakentaa näkyviin, että hän on hankkinut itsestään uutta ymmärrystä ja että hänellä on tarkkaileva ja arvioiva suhde itseensä?

Itsereflektiivisyys ei sinänsä ole toiminto tai puheenvuoron laji, vaan pikemminkin vuoron muotoilun tapa. Itsereflektio kuitenkin tapahtuu aina vuorovaikutuksessa jonkin toiminnon osana ja toimittaa jotain vuorovaikutuksellista tehtävää. Tässä tehtävänä on nimenomaan vakuuttavuuden ja evidenssin rakentaminen voinnin muutokselle haastattelupuheessa.

Itsereflektiota tarkastellaan psykoterapian vaikuttavuustutkimukseen kerätyistä tutkimushaastatteluista. Aineisto on osakorpus laajasta tuloksellisuustutkimuksesta The Helsinki Psychotherapy Study (HPS), jossa tutkitaan neljän psykoterapian tuloksellisuutta masennus- ja ahdistusoireiden hoidossa. Osakorpus on kerätty keskustelunanalyysiä soveltavan laadullisen tutkimuksen käyttöön. Hankkeessa kartoitetaan psykoterapeuttista haastattelua vuorovaikutustilanteena 
ja selvitetään kielellisiä keinoja, joilla potilaan vointi ja mieli tuodaan vuorovaikutuksessa tarkastelun kohteiksi. ${ }^{1}$

Itsereflektiota tarkastellaan osana kuvauksia, joissa potilaat kertovat vointinsa kohentuneen. Useat sosiaaliset käytännöt jäsentyvät niin, että toimijat orientoituvat "arjen hyväntahtoiseen järjestykseen” (Maynard 2003). Taustaoletus on, että maailma on hyväntahtoinen, asiat ovat hyvin, ja poikkeamaa tästä käsitellään merkillepantavana, selostettavana asiana. Sen sijaan ko. haastatteluissa lähtöoletus onkin alkujaan huono asiantila, syy jonka takia potilas on hakeutunut terapiaan. Merkittäväksi kuvattu muutos voinnissa on tällöin selontekoa vaativa asia. Tehdäkseen selkoa vointinsa muutoksesta ja osoittaakseen sen potilas rakentaa puheeseensa. itsereflektiivisyyden elementtejä.

\section{POTILAAN VOINTI PUHEENA SEURANTAHAASTATTELUSSA}

HPS:ssä potilaiden vointia seurataan lukuisin psykologisin testein sekä videoiduin haastatteluin, jotka toistuvat useita kertoja 5 vuoden seurantajakson aikana. Potilaat kuvaavat vointinsa muutoksia ja arvioivat saamaansa terapiaa. Haastattelija arvioi potilaan vointia diagnostisesti, muttei esitä arvioitaan potilaalle. (Knekt \& Lindfors 2004.)

Vointia koskevaan kysymykseen vastataan arviolla, arvottavalla lauseella. Arviota joko hyvästä tai huonosta hakee myös haastattelija. Hyvä ja huono eivät kuitenkaan ole yksiselitteisiä, ja vointia käsitellään usein osa-alueittain. Potilaat paitsi tulkitsevat olojaan ja niiden muutoksia, myös joskus problematisoivat kriteerejä, joilla niitä arvioivat. Lisäksi vointia ei ainoastaan kuvata, vaan perustellaan ja selitetään (vrt. Tontti 2000). Usein potilaat lisäksi osoittavat pitävänsä vointinsa kohenemiseen pyrkimistä moraalisena vastuunaan.

Vointi ei aina tietenkään ole kohentunut. Vointi voidaan kuvata huonona, huonontuneena tai ennallaan olevana. Itsereflektiivinen puhe rakentuu eri tavoin eri yhteyksissä, ja vointikuvauksetkin rakentuvat eri tavoin riippuen siitä, kuvataanko huonoa vointia terapiaan hakeutumisen syynä vaiko terapian saamisen jälkeistä kohentunutta tai heikentynyttä vointia. Tässä keskitytään analysoimaan kohentuneen voinnin kuvauksia. Termivalinta on tietoinen: tarkoitus ei ole samaistaa potilaan vuorovaikutuksessa esittämiä kuvauksia siihen, onko potilas kliinisesti katsoen parantunut. Haastattelijoiden mukaan nämä arviot eivät nimittäin läheskään aina kohtaa.

Kohentunut vointi tulee puheeksi haastattelujen alussa. ${ }^{2}$ Tätä analyysiä varten on tarkasteltu puolistrukturoituja alkuosuuksia keskittyen yleisvointia kartoittavaan alkukysymykseen sekä siihen kytkeytyviin elämänmuutoksia kartoittaviin kysymyksiin 2-3 (ks. alla). Kolmen ensimmäisen kysymyksen aihepiirit kietoutuvat usein potilaan vastauksissa toisiinsa.

1. Voisitko kertoa tämänhetkisestä voinnistasi ja tilanteestasi, mahdollisista vaikeuksistasi ja ongelmistasi?

- miten elämä sujuu ja mihin olet tyytyväinen?

- minkälaisia ongelmia tai oireita on edelleen?

2. Minkälaisia muutoksia olet havainnut viimeisten (kulunut aika) kuukausien aikana (= edellisen seurantahaastattelun jälkeen)?

- voinnissasi

- ihmissuhteissasi

- työ- ja toimintakyvyssä ja

- vapaa-ajan vietossasi?

3. Minkälaisia ulkonaisia muutoksia elämässäsi on tapahtunut kuluneena aikana?

- mitä muutokset ovat merkinneet?

HPS haastatteluagendan kysymykset 1-3 (Knekt \& Lindfors 2004)

Haastattelukysymykset ovat moniosaisia ja kutsuvat laajaan vastaukseen. Kysymyksissä on usein varovainen, ehdottava muotoilu (”jos ihan kertoisit...”) sekä viittaus edellisestä tapaamisesta kuluneeseen aikaan. Alkukysymykset mahdollistavat potilaalle liikkeellelähdön joko koetusta olotilasta tai "ulkoisista” elämänolosuhteista. Haastattelukysymykset mahdollistavat itsereflektiivisen puheen, mutteivät edellytä sitä. Omaa elämää ja vointia voi kuvata ilman itsereflektiotakin: kuvaamalla olotiloja, konkreettisia tapahtumia, esittämällä tunnepitoista valittamista tai huolenkerrontaa. Itsereflektiopiirteet sen sijaan demonstroivat puhujan tarkkailleen, tulkinneen ja arvioineen itseään sekä oppineen jotain itsestään.

Haastattelija vaikuttaa haastatteluun tietysti paitsi kysymyksin, myös potilaan vastauksia vastaanottavilla vuoroillaan. Meneillään olevan väitöskirjatutkimuksen mukaan (Ehrling 2004) ne vaihtelevat mm. sen suhteen, kuinka valmiina tai riittävänä ne potilaan vuoroa kohtelevat. 
Keskustelunanalyysin periaatteiden mukaisesti analyysi tukeutuu nk. sekventiaaliseen evidenssiin, eli analyysi perustuu molempien osapuolten toiminnan tarkasteluun vuorovaikutuksen kulussa. Kohentuneen voinnin kuvauksen vakuuttavuus onkin asia, johon molemmat toimijat orientoituvat. Haastattelija ei kohtele riittävänä sellaisia kuvauksia, joissa itsereflektio- ja vakuuttavuuspiirteitä ei esiinny, vaan pyytää laajennusta tai uudistaa yleisvointikysymyksen. Kun potilas puolestaan vastaa laajennuspyyntöihin, hän muokkaa kuvaustaan lisäämällä itsereflektiivisyyden piirteitä niin, että sisäinen muutos tulee vakuuttavammin osoitetuksi. Tässä artikkelissa sekventiaalisen evidenssin sijasta keskitytään kuvaamaan itsereflektiivisen puheen piirteitä.

\section{KOHENTUNEEN VOINNIN KUVAUKSET}

Seuraava analyysi kuvaa, miten potilas muotoilee vointiarviotaan. Vuoron muotoilu (turn design) on eräs keskustelunanalyysissa käytetty analyyttinen näkökulma. Vuoron kantamaa toimintaa sekä toiminnan muotoilua tarkastellaan puhujan valintana, jossa näkyy orientoituminen käsillä olevaan institutionaaliseen tehtävään, puhujien vä- lisiin suhteisiin tai puheena olevan asian vaatimuksiin (Heritage 1997, 170-173; ten Have 1999, 119-127). Tässä se tarkoittaa potilaan orientoitumista odotukseen, että voinnin muutos vaatii evidenssiä. Voinnin muutos osoitetaan mm. itsereflektiota demonstroimalla.

Seuraavassa esitellään kaksi uutta vointikuvausta, sitten eritellään kuvausten piirteitä yksilöidymmin HPS-aineiston otteiden perusteella. Otteet edustavat laajempia kokoelmia. Litteroinneissa sovelletaan keskustelunanalyyttistä tapaa, mutta transkriptioita on karsittu luettavuuden takia. Esimerkeissä kuukausitunnus viittaa kuluneeseen aikaan terapian aloittamisesta, lisäksi kerrotaan, mitä terapiaa potilas on käynyt.

Potilas taustoittaa vointikuvauksensa terapiamaininnalla ja implikoi näin paranemisen kytkeytyvän terapiaan. Seuraa vointiarvio, joka sisältää ääri-ilmauksen "paljon paremmi”, jota vielä voimistetaan vertaamalla oloa aiemmin koettuun hyvään tilaan (r. 8-10). Potilas laajentaa välittömästi kuvaustaan. Hän kuvaa vähittäistä luisumistaan masennukseen tilana, jota ei ole tunnistanut, mutta esittää tunnistavansa nyt sen päättyneen. Näin hän tarjoaa voinnin paranemisen evidenssiksi kykyään arvioida vointiaan. Sitten potilas siirtyy luettelemaan asioita, joista tunnistaa olon-

\section{ESIMERKKI 3 [60 KK / LYHYT PSYKODYNAAMINEN]}

1 HA: no niin () kerros nyt vähän () kuinka mitess täs viime aikoina mennyt () siit on kaks vuotta 2 sitten ku () tavattiin.

3 PO: mähän on ollu nyt tota niin () ym () niinku () terapiassa

4 HA: jo[o

5 PO: [muuta kautta () joka alkaa päättyä nyt () e () e et tota () ööm () se oli ((nimeää rahoitus 6

HA: $[(-) \quad$ [joo

PO: $\quad$ viikossa () ja tota () mä niinku selvästi tunnistan että () et mä voin () niinku () paljon paremmi tai ei oikeestaan edes paljon paremmin vaan mä oon palannu johonki sellaseen jossa mä oon ollu kymmenen vuotta sitte () niinku semmoseen () et mä tunnistan että () mul on ollu semmmonen () hiljalleen laskeutuvah hh alamäki () masennusmäki () jota ei tavallaan niinku () varmaan () ku ei o () se ei ollu mikän dramaattinen se laskeutuminen ni mä en oo pystyny tunnistaa mut nyt mä tunnistan että se on ohi () et tota m () et mistähän se ojo jostaki s siitä ku must- mun mielestä taas on öö () kaikki tuntuu mukavalta siin tuli () jos jossain vaiheessa alku () alkukeväästä se mä aloin huomata sen ja () mul oli vähän aikaa semmonen hirveen euforinen olo semmonen kaikki on ihanaa ja kaikki on hyvin () et se on nyt ehkä siitä sit laskenu niinkuu () vähän mut että () et niinku () yksinkertasest sillai että () mä en ole väsynyt () sillä lailla () m mä en ole semmosessa pysyvässä burnoutissa niinku mä oon ollu () niinku () jatkuvasti () ja () mä oon hyväntuulinen () mä uskon jotenki (mahdollisuuksia elämään) ja () ja () no e- mitähän vielä () sis ylipäätänsä siis olo on () selkeesti s () selvästi toisenlainen. 
sa muutoksen. Omaa puhetta editoiva kysymys (r. 13; ”et mistähän se o- ") osoittaa, että potilas orientoituu puheessaan perustelemistehtävään. Hän kuvaa ensin euforista onnea, sitten oireiden puuttumista, lopuksi listaa vielä myönteisen olotilan ja asennoitumisen havaintoja. Sen jälkeen hän taas editoi puhettaan ”mitähän vielä” (r. 20), jolla myös osoittaa orientoituvansa perustelemi- sen tehtävään. Hän on tähän asti pitänyt aktiivisesti vuoroa, mutta nyt esittää vuoroa lopettavan yhteenvedon "olo on selkeesti- selvästi toisenlainen".

Seuraavassa toisentyyppinen vointikuvaus:

Aluksi vastauksessa näkyy vastaamisen vaikeus; tauot ja hakuilmaus (r. 6-9). Asia konstituoituu tulkinnanvaraiseksi: vointi ei ilmene koke-

\section{ESIMERKKI 4 [24KK/LYHYT PSYKODYNAAMINEN]}

((PO aloittanut sanomalla että "mulle kuuluu kyllä ihan hyvää”, sitten kuvannut opiskeluaan ja viihtymistä uudessa työpaikassaan))

HA: no entäs muuten jos ajattelet (just et) () iha îhmissuhteita perhesuhteita () kuvasi itsestä si () tällaisia asioita onko sinulla mitään erityisiä munutoksia tapahtunu mielestäsi .hh nyt niinku vuoden aikana,

((usean sekunnin hiljaisuus))

PO: $\quad \mathrm{mmm}$

PO: $\quad$ mitä mä nyt sitte sanoisin () ku mä täytin niitä () papereita nyt () ni mä hūomasin (et) () et jotain () ainaki mulle s () jäi itelle semmone olo et jotain on niinku müuttunu () mus kuiitenkii () että () no tehän näätte täällä että () et kuinka paljon mä oon vastannu ((naurahtaen)) eri tavalla [tai samalla tavalla ku

HA: [joo,

PO: $\quad$ aikasemmi () (mut et) îtellä mulla oli semmonen olo

0

HA: ahaa.

PO: et mä en oo nịin kipee () sisältä

0

HA: kuin,

PO: $\quad$ kuin () (kuin vielä) vuosi sitten,

HA: ahaa (o[saatko) () (osaatko) (-[-)

PO: [(tiesin) [jotenki se ku mulla on se hylkäämisen hava () ollu semmonen kạuheen kipee () ja se () mikä on siitä isäsuhteesta () mm mikä on niinku () ollu () tai mikä on niinku () mun îsäsuhteesta se ku isä alkoholisoitu sillon ku mä olin pieni ()

HA: $\quad$ mm.

0

PO: ja kaikki mikä on siitä noussuh () ni mä () mä niinku () luulen että se on vaikuttanu @hirveesti munihmissuhteisii@

0

HA: $\quad$ mm.

PO: mun ystävyyssuhteisiin mun () suhteeseen () miehii jahh ylipäänsäh niinku mun itse tuntoon

0

HA: [joo.

((usein sekuntien tauko))

PO: ja:, () mä koen että () et tsiin on nyt tapahtunu () parantumista () et syksyllä ku mä olin siel projektityön () kurssilla...

((seuraa laaja kuvaus siitä miten PO käyttäytyi kurssilla mieskurssitoverien kanssa luontevammin, nautti oppimisesta ja oli aktiivinen)) 
muksessa suoraan. ${ }^{3}$ Vointiarvion muotoilu myötäilee haastattelijan kysymyksen muotoilua: “jotain on niinku muuttunu” (r. 10). Haastattelija vastaanottaa ilmauksen uutisena ("ahaa”, r. 16), odottaen silti jatkoa. "Jotain on muuttunu" on jatkoa ennakoiva ilmaus, se vaatii "jonkin” purkamista. Potilas jatkaakin: "en oo niin kipee sisältä” (r.17). Ilmaus kuvaa huonon asiantilan poissaoloa. Se on kokonaisvaltaista kokemusta kuvaava viittaus sisäiseen maailmaan, jota terapiassa työstetään. Toisin kuin "masennus” tai "burnout” se ei ole kliininen termi, ja vaatii siksikin purkamista. Haastattelija pyytää tätä (r. 21) ja potilas jatkaa taas metaforisella ilmauksella: sisäisen kipeyden on aiheuttanut "hylkäämisen haava", jonka taustaa potilas alkaa selvittää syy-seuraus-suhteita kuvaavalla tulkinnalla.

Tulkinnalla on yhtäläisyyksiä psykoanalyysissa esitettyjen potilaan tiedostamatonta mielen aluetta luonnehtivien tulkintojen kanssa (Peräkylä 2004; Vehviläinen 2003): lapsuudessa koettu vaikea asia selittää aikuisena koettua kärsimystä eri elämänalueilla. Kuvauksen affektinen huippu on kohdassa "mä niinku luulen että se on vaikuttanu hirveesti mun ihmissuhteisii”. Äänen laatu muuttuu, se välittää tuohtumusta. Selitys esitetään totaalisena ja perustavana. Lopuksi potilas toteaa, että "siinä on nyt tapahtunu parantumista”. Tämän jälkeen hän etenee kuvaamaan kurssikokemustaan (r. 37->, ei otteessa). Laaja ettäalkuinen kuvaus myönteisestä käyttäytymisestä on kuultavissa evidenssinä sisäiselle parantumiselle.

Edellä esitetyt kolme HPS -aineiston esimerkkiä muodostavat tarkastelupohjan, kun seuraavassa esitellään tarkemmin vointiarvioiden kielellisiä piirteitä. Otteissa potilaat perustelevat vointinsa kohenemista erilaisella ”näytöllä”, liittäen arvioon sitä tukevia, muutosta demonstroivia elementtejä.

Kohentuneen voinnin kuvaukset ovat arvioita. Ne sisältävät olotilan, toiminnan tai asennoitumisen luonnehdintoja sekä niiden muutosta kuvaavia havaintoja. Usein esitetään ensin yleisarvio, jonka jälkeen kuvausta välittömästi laajennetaan. On tavallista esittää negatiivinen havainto, kuvata huonon asiantilan poissaoloa. Tällaisia ovat esimerkin 3 ilmaukset "mä en ole väsynyt”, "mä en ole semmosessa pysyvässä burnoutissa”, esimerkin 4 "kipee sisältä” ja esimerkin 1 "ei vaadi niin paljoo iteltää", "ei niin herkästi syyllistä itseänsä”. Negatiivista havaintoa hyö- dyntävä kuvaus perustuu normalisoimiseen: oire on poikkeava asiantila, sen poissaolo puolestaan normaalia - arjen hyväntahtoinen järjestys palaa. Positiivinen havainto sen sijaan kuvaa olemassa olevaa, hyvänä esitettyä olotilaa ja sen sisältöä, kuten esimerkissä 3 esiintyvät ilmaukset "kaikki tuntuu mukavalta” ja "mä oon hyväntuulinen” tai esimerkin 1 "niinku on paljon varmempi”, ”tapahtuu paljon luontevammin”.

\section{ITSEREFLEKTIIVISYYS KOHENTUNEEN VOINNIN KUVAUKSESSA}

Seuraavaksi tarkastellaan lähemmin itsereflektiota rakentavia piirteitä.

\section{Voinnin muutoksen selittäminen ja attribuoimi- nen}

Kohentuneen voinnin kuvauksissa on yleensä mukana selityksiä tai attribuointeja: viittauksia voinnin muutokseen vaikuttaneisiin asioihin. Ääriesimerkki olisi otteessa 4 näkyvä "diagnostinen” selitys ongelmien ydinsyystä. Selitys voi viitata myös olosuhteisiin, kuten avioeroon tai työpaikan vaihtoon. Tavanomaista on myös esittää positiivisia havaintoja niin, että ne implikoivat potilaan aktiivista mentaalista prosessia ja oppimisen osuutta voinnin muutoksessa. Muun muassa esimerkin 1 riveillä 2-3 näkyy kuvaus oppimisesta, ja potilas esiintyy kuvauksessa toimijana. Kun puhuja ei lisäksi enää "vaadi niin paljoo itseltää" tai "ei syyllistä itseänsä” (r. 6) hän implikoi ennen vaatineensa ja syyllistäneensä, ja nyt osaavansa toimia toisin. Hän implikoi paitsi oppimisen, myös vastuun asiasta. Oppimisen, kykenemisen ja pystymisen kuvaukset implikoivat siis myös selitysmalleja: kun kuvataan, mitä vahingollista tai tarpeetonta ei enää tehdä, implikoidaan että oma toiminta piti ongelmaa yllä.

\section{Itsen tarkkailua ja havainnointia osoittavat kie- lelliset piirteet}

Kohentuneen voinnin kuvaukset sisältävät kielellisiä piirteitä, jotka tuovat näkyville itsen tarkkailun projektin; itseään havainnoivan ja tarkkailevan minän. Esimerkki 1 sisältää viittauksen “huomaamiseen”, (r. 10), jolla potilas rakentaa näkyviin itseä tarkkailevan minän, esittäen puheensa havainnon tuloksena. Samoin esimerkin 3 potilas puhuu "tunnistamisesta” (r. 8, 10, 12) ja huomaamisesta (r.14). Huomata-verbi (myös Esimerkki 
2, r.4, 5 ja Esimerkki 4, r. 8) korostaa havaitsijan positiota - asia ikään kuin vaatii havaitsijan huomiota. Tunnistaa-verbi taasen implikoi havainnon sijoittamista jo tunnettuun kategoriaan. Näin implikoidaan subjekti, jonka tehtävänä itsen tarkkailu on ja joka tekee tätä tarkkailua pitkäkestoisesti, "projektina”. Lisäksi esimerkissä 4 potilas kuvaa havaintonsa lomakkeen täytön yhteydessä: havainto itsen tilasta syntyy siis lomakevastauksia havainnoimalla (r. 8-16).

\section{Oman kokemuksen "osittainen omistaminen"}

Ehkä huomionarvoisin vuoron muotoilun piirre vointikuvauksissa on, että omaa kokemusta käsitellään usein ehdottavasti, vain osittain tunnettuna. Esimerkissä 4 puhuja käyttää tuntemukseen ja kokemukseen viittaavaa metaforaa "olla kipee sisältä”, mutta esittää havaintonsa lomakkeen täytöstä seuranneena, ikään kuin ulkopuolelta syntyneenä päätelmänä. Hän myös lisää parenteettisen "ainaki mulle jäi itelle semmonen olo" (r.10) ja myöhemmin toistaa "mut et itellä mulla oli semmonen olo" (r. 14), jotka myös implikoivat oman näkökulman rajallisuuden. Selvimmin tämä ehdottava, ei-auktoriteettinen sävy syntyy parenteettisesta viittauksesta lomakkeisiin, jotka luovat "objektiivisemman" kuvan potilaan voinnista (r. 10-14). Myöhemmin potilas esittää tulkintaehdotuksen: "mä luulen että se on hirveesti vaikuttanut mun ihmissuhteisiin” (r. 27-28). Myös otteen 1 formulointi “siinä mieles varmaan se oma itsetunto on nin kun nousussa” (r.18) ja esimerkin 2 "mä uskoisin että mä oon niinku - jollakin tavalla itse tuota - ruvennu muuttuu" (r. 8) esittävät luonnehdinnan ehdottavasti, kuin ulkopuolisen näkökulmasta ${ }^{4}$ - päättelyn tai tulkinnan pikemmin kuin kokemuksen tuloksena, ikään kuin ulkopuolisen näkökulmasta. Näin on tavallista muotoilla puhetta, joka koskee jonkun toisen kokemusta (Peräkylä \& Silverman 1991; Peräkylä 1995, 103-143). Kun tähän tapaan puhutaankin omasta kokemuksesta, se tuottaa puheelle erityisen itsereflektiivisen, terapiakulttuurisen sävyn. Puhetapa implikoi tiedostamattoman, alueen jolle kokijalla itselläänkin on vain osittainen pääsy (vrt. Vehviläinen 2003; 2004). Puhuja on ikään kuin tutkimassa oman mielensä piileviä, tuntemattomia alueita, ja joskus psykoterapeuttiselle ammattilaiselle voidaan attribuoida suurempi pääsy näille alueille: lomake tai ammattilainen voi joskus "tietää paremmin” mitä potilaan mielessä on.
Edellä kuvatut kielelliset piirteet rakentavat itsereflektiota. Niiden kautta rakentuu näkyviin itseä tutkiva, tarkkaileva minä. Itsetarkkailu on projekti, jossa puhuja kerää tietoa havainnoimalla, päättelemällä ja tulkitsemalla, ei ainoastaan välittömän kokemuksen kautta. Puhuja kuvaa havainnoimaansa usein ehdottavasti, ei-asiantuntijan positiosta käsin.

\section{RETORISET KEINOT: MUUTOKSEN USKOTTAVUUS}

\section{Abstraktiotason vaihtelu}

Kohentuneen voinnin kuvaukset sisältävät usein sekä kokoavia käsitteitä että niitä tukevia konkreettisia esimerkkejä, eli niissä vaihdellaan abstraktiotasoa. Otteessa 1 (r. 10) esiintyy tällainen siirtymä, samoin esimerkin 4 puhuja siirtyy otteen jälkeen esittelemään konkreettista esimerkkiä paranemisestaan, jonka on ensin kuvannut abstraktisti, metaforin. Vakuuttavuuden näkökulmasta abstraktiotason vaihtelu on merkki sisäistyneestä näkemyksestä. Jos puhuja esittää pelkän abstraktion ("kyllähän sitä nyt tuntee ittesä paremmin”) muttei konkretisoi kuvausta, se olisi alttiimmin kuultavissa mekaanisena lauseena. Jos taas vain luetellaan havaintoja, muttei sidota niitä mihinkään perspektiiviin, havainnot eivät ilmennä kokoavaa oivallusta, tulkintaa. (Vrt. Edwards 1995, 1999.)

\section{Vakuuttelupiirteet}

Kuvauksissa esiintyy lukuisia vakuuttelukeinoja, joilla argumentoidaan arvion puolesta, osoitetaan että kuvatut ilmiöt ovat todellisia (vrt. Edwards 1995). Eräs keino, joka näkyy esimerkin 3 laajennuksessa alla (r.10-14) on onhan-toki-ongelmiakin -myönnytys (vrt. showing concessions, Antaki \& Wetherell 1999). Myönnytys on upotettu paranemiskuvauksen sisään, ja se sisältää realistisuutta rakentavia viittauksia itsestäänselvään (totta kai, han- pääte r. 10-11). Ongelmamyönnytyksen jälkeen palataan kohentuneen voinnin kuvaukseen yhteenvedolla, joka tekee mahdolliseksi hyvän voinnin ja ongelman yhtäaikaisen läsnäolon: "mut että mun on ehkä niinku helppo olla itseni kanssa” (r. 15) .

Myönnytys-keino on mahdollisiin vastaväitteisiin varautumista (Antaki \& Wetherell 1999, Nikander 2002, 132-140). Jos kuvaus paremmasta voinnista on liian ylenpalttinen, se ei vaikuta realistiselta. Siksi ongelmamaininta hyvän voin- 


\section{ESIMERKKI 3 (LAAJENNUS)}

1 Ha: joo-o? () (ja tää on niinku alkukeväälläkö siis)

2 Po: hiljaa () joo siis vähän hiljall[een ehkä

3 Ha: [mm

$4 \quad$ Po: niinku () tapahtu () et mä muistan silloin ku mä olin n- nuorempi. () mä muistan kun mä ajattelin usein et () elämä oli niin hirveen mukavaa että () oli aamulla hirmu kiva et herätä ja niinku () heittää peitto päältä nopeesti ja hypätä ulos niinku lapset. () ni mul on vähän jotain samanlaist sellasta että () et jotain semmosta () optimismia ja hyväntuulisuutta. kaikki tuntuu () mukavalta

8 9 Ha: joo

10 Po: eikä se tiet eikä ehkä ei eikä varmaankaan niinku sillai mitään ongelmia ei olis siis mullhan 11 on viisitoistavuotias poika ni totta kai () päivittäist karjumista milloin mistäki ja tällasta et 12

13 Ha: [mmm [nii

14 Po: mitään ei olis ja () työasiois jos hankaluuksia niis on hankaluuksia edelleenki () mut että 15 () mun on ehkä niinku helppo olla () itseni kanssa

16 Ha: joo-o. () no () kerros nyt...

nin kuvauksen osana voi lisätä vakuuttavuutta. Tällä keinoin potilas voi osoittaa, että muutos on nimenomaan sisäinen, asennoitumisen muutos, ei vain ulkoisiin olosuhteisiin liittyvä. Myönnytyskeino näyttää olevan erityisen tarpeen silloin, kun kuvaus on aloitettu totaalisella tai äärimmäisellä hyvän voinnin ilmauksella. Tässä potilaan loppupäätelmä onkin rakennettu ehdottavaksi tulkinnaksi: "mun on ehkä niinku helppo olla itseni kanssa".

Vakuuttavuutta tukee siis myös oman kokemuksen ehdottava, varovainen kuvaaminen. Terapiaan liittyvässä kontekstissa tähän on kaksi syytä. Ensiksi: etenkin diagnostista ammattitermistöä hyödyntävä kuvaukset (itsetuntoon, toimintakykyyn, masennukseen tms. liittyvät kuvaukset) altistuvat "professionaalille skeptisyydelle”- onhan käsillä asiantuntemusta ja tutkimusaineistoa joka voisi periaatteessa diskvalifioida potilaan kuvauksia. Ehdottavuus suojaa tältä skeptisyydeltä. Toiseksi: ehdottavuus tuottaa kuvan vähittäisestä, hiljalleen aukeavasta prosessista: minää ei opita tuntemaan yhtäkkiä eikä lopullisesti. Täysin varmoiksi rakennetut, finalistiset ilmaukset eivät uskottavasti osoita puhujan olevan matkalla suurempaan itseymmärrykseen. Päinvastoin, juuri "liian varmat”, evidenssittömät hyvän voinnin kuvaukset herättävät aineistossa haastattelijan laajennuspyyntöjä ja vointikysymyksen uudistamista.

Muitakin vakuuttelukeinoja näkyy esimerkeissä runsaasti. Esimerkissä 4 potilas käyttää vakuuttelevia ilmauksia kuten ”kauheen” (r. 23) ja "hirveesti” (r. 28). Lisäksi esimerkin 3 potilas "selvästi tunnistaa” (r.8) ja olo on "selkeesti- selvästi toisenlainen” (r. 21). Selvä -sana on paitsi vakuutteleva ilmaus, myös havaitsijan positiota korostava. Lisäksi puhuja kuvaa äärimmäistä hyvää tilannetta korjatessaan ilmauksen "paljon paremmin” vahvemmaksi: "tai ei oikeestaa edes paljon paremmin vaan (ennalleen)” (r. 9-10). Lisäksi samassa otteessa "kaikki tuntuu mukavalta" (r. 14).

\section{MIKSI KOHENTUNUT VOINTI ON SELONTEKOA JA \\ TODENTAMISTA VAATIVA ASIA?}

Psykoterapian seurantahaastatteluissa potilaat tekevät "vakuuttelutyötä”: he osoittavat, että muutos voinnissa on todellinen ja systemaattinen. Parisuhdepuheen retoriikkaa tutkinut Derek Edwards (1995, 1999) on löytänyt vastaavia keinoja (scripting devices). Ne ovat puhujan tapoja osoittaa, että toisen henkilön käyttäytyminen on "skriptin" mukaista; ilmentää jotain asennetta tai luonteenpiirrettä. Edwards tarkastelee vuorovaikutusta parisuhdeterapeutin vastanotolla, jossa puolisot valittavat toisistaan, suojaten samalla omaa kuvaustaan toisesta mahdolliselta skeptisyydeltä ja kumppanin syytöksiltä.

Syyttelyn leimaamassa parisuhdepuheessa vakuuttelutarve tuntuu ymmärrettävältä. Miksi se on tarpeellista omaa kokemusta koskevassa puheessa? Kohdellaanhan potilasta seurantahaastattelussa nimenomaan kokemuksensa omistajana (vrt. Peräkylä \& Silverman 1991; Peräkylä 1995; 
Vehviläinen 2003). Silti voinnin koheneminen vaatii selontekoa ja evidenssiä. Ensinnäkin: voinnin koheneminen on institutionaalisesti odotuksenmukaista, muttei varmaa. Toiseksi: kaikkiin terapioihin kuuluu mahdollisuus "professionaaliin skepsikseen": ajatus, että potilaan kuvausta voinnistaan voi olla syytä (ja institutionaalinen lupa) epäillä. Ajatellaan esimerkiksi, että potilas voi kaunistella tilannettaan ja torjua kipeitä asioita tietoisuudestaan. Kolmanneksi: potilaan oma suullinen kuvaus voinnista vertautuu tutkimuksessa erilaisin testein tuotettavaan kuvaukseen, eivätkä testitulokset aina vastaa potilaan kuvausta.

Mikä tärkeintä, voinnin muutoksen ymmärretään terapiakontekstissa vaativan sisäistä muutosta. Kohentunut vointi ei todennu vain erilaisena olona, vaan dynaamisena muutoksena mielessä, joka näkyy ymmärryksessä, asenteissa ja toimintatavoissa. Haastattelun molemmat osapuolet kohtelevat kuvausta tyhjentävänä silloin, kun se ilmentää itsereflektiota ja sisäistä muutosta, ei pelkkää olosuhteiden tai olotilan muutosta. Voi kuulostaa paradoksilta, että vakuuttavuutta lisää oman kokemuksen tentatiivinen, ehdottava kuvaaminen. Se on kuitenkin linjassa institutionaalisen (psykoterapeuttisen) kontekstin kanssa: Omaa mieltään on todella tutkinut se, joka tajuaa ettei tunne sitä kokonaan.

\section{ITSEREFLEKTIO PUHETAPANA TERAPISOITUVASSA KULTTUURISSA}

Tämä artikkeli tarkasteli itsereflektiota kielellisenä ja vuorovaikutuksen aikaansaannoksena. Lienee mahdollista tarkastella refleksiivistä itsesuhdetta eräänlaisena instituutiona, johon orientoidutaan monissa ympäristöissä kielellisten tai vuorovaikutuskäytänteiden tasolla ja myös moraalisesti sitovana asiana.

Artikkelissa kuvattiin itsereflektiopiirteitä vakuuttelun ja perustelemisen keinoina kohentuneen voinnin kuvauksissa. Erityisesti käsiteltiin a) "itsen tarkkailun projektia” osoittavia kielellisiä piirteitä; b) voinnin selittämistä osana itsereflektiota, c) oman kokemuksen "osittaista omistajuutta” ja d) vakuuttamisen keinoja. Psykoterapian seurantahaastatteluja voi vertailla itsereflektiopiirteiden osalta sekä pitkittäis- että poikittaistarkasteluina ja selvittää itsereflektiivisen puheen osuutta ja asemaa haastatteluissa. Lisäksi voidaan tunnistaa itsereflektiivisen puheen käyttöä muissa konteksteissa, kuten aikuiskoulutuksen, itsen kehittämistoiminnan ja informaalien arkipäivän oppimistilanteiden vuorovaikutuksesta ja paikantaa tehtäviä joita itsereflektiivinen puhe eri konteksteissa saa. Tämän artikkelin otteissa itsereflektio esiintyi nimenomaan myönteistä vointiarviota perustelemassa - toisenlaisia ympäristöjä olisivat vaikkapa ongelmista puhuminen, avun tarpeen perusteleminen, parisuhdepuhe tai riita. Lisäksi alustavien vertailujen mukaan itsereflektiivinen puhe asettuu varsinaisessa terapiavuorovaikutuksessa hyvinkin erilaisiin käyttöihin eri terapioissa.

Käsitelty osakorpus on sikäli rajallinen, että kaikki tarkastellut potilaat ovat naisia. Esimerkissä 2 näkyy, että AA-lainen miespuhuja itsereflektoi sujuvasti, mutta usein tämä puhetapa attribuoidaan keskiluokan ohella nimenomaan naisille (Kivivuori 1991, vrt. Tainio 2001a; 2001b, 135161; Näre 1999, 274-275). Toisinaan esitetään, että naiset ovat tällaisissa puhetavoissa niin suvereeneja, että lyövät miehet ulos parisuhteista ja työelämästäkin (vrt. Cameron 2000, 140-146). Psykokulttuurin tuottajat (kuten parisuhdeoppaiden kirjoittajat, terapeutit ja itsetuntemuskouluttajat) ovat kuitenkin sekä miehiä että naisia, ja he suosittavat itsereflektiivistä puhetapaa kaikille mm. parisuhteiden pelastukseksi ja hyvinvoinnin edistämiseksi (vrt. Tainio 2001b, 26-27; Cameron 2000).

Se, miten ihmiset eri tilanteissa käyttävät itsereflektiivistä puhetta, on empiirinen, myös aikuiskasvatustieteelle lankeava kysymys. Aikuiskoulutuksen ammatit ovat saaneet auttamistyön piirteitä (Baumgartner 2001, 21), ja viime aikoina on alettu keskustella koulutuksen mahdollisesta "terapeuttisesta käänteestä” sekä sen mukaisesta aikuiskouluttajien roolin muutoksesta ja laajenemisesta (Usher ym. 1997; Glastra ym. 2004). Tulisiko jo pohtia, mitä terapeuttinen käänne tarkoittaisi suomalaisessa aikuiskoulutuksessa, halutaanko sitä hallita tai hillitä, tulkita tai edesauttaa, ja mitä se edellyttää oppijoilta sekä aikuiskasvatuksen ammattilaisilta?

\section{VIITTEET}

1. Helsingin yliopiston dosenttiapurahan rahoittama Vehviläisen hanke ”Terapiapotilaan itsereflektiivinen puhe” on osa Anssi Peräkylän johtamaa Suomen Akatemian rahoittamaa hanketta "Vuorovaikutuksen tuloksellisuus terveyden- 
huollossa ja sosiaalipalveluissa”. HPS:n taholta yhteistyökumppaneina ovat olleet HPS:n johtaja Paul Knekt sekä tutkimuspäällikkö Olavi Lindfors.

2. Analyysissa käytetty 48 nauhoitteen osakorpus käsittää kuusi nauhoitetta kahdeksalta potilaalta, joista kaksi on käynyt tai käymässä psykoanalyysia, kolme pitkäkestoista psykodynaamista ja kolme lyhytkestoista psykodynaamista terapiaa. Tästä aineistosta on käyty läpi 29 haastattelua (terapian aloituksesta 7-60 kk), joista yhdeksän potilasta kuvaa vointinsa keskeisellä tavalla kohentuneen.

3. Tulkinnanvaraisuuteen orientoitumista osoittaa myös haastattelijan sana ”mielestäsi” (r. 4).

4. Alustavan vertailun pohjalta voi todeta, että ”tentatiivinen” tapa puhua oman mielen sisällöistä näkyy muissakin konteksteissa, kuten psykoanalyysiaineiston itsereflektiivisissä otteissa.

\section{LIITE}

Litteraatiota on karsittu runsaasti, mikä tuottaa sujuvuutta lukemiseen, mutta tarkoittaa myös sitä, että kaikki esimerkkien analyysissä alun perin vaikuttaneet vuorovaikutuksen piirteet eivät ole enää näkyvissä. Tarkemmat litteraatiot ko. otteista on saatavilla kirjoittajalta.

Artikkelissa esiintyvät seuraavat keskustelunanalyyttiset litteraatiomerkit (vrt. Seppänen 1997)

PO: potilas

HA: haastattelija

sana painotus

@sana@ selvä muutos äänen laadussa

() kuultavissa oleva tauko puheessa

(()) litteroijan huomioita

[ ] päällekkäispuhunta

(sana) litteroijan arvio epäselvän sanan sisällöstä

(--) epäselvä sana/sanoja

mit- katkaistu sana

\section{KIRJALLISUUS}

Antaki. C \& Wetherell, M. (1999). Show concessions. Discourse Studies 1: 7-27

Arminen, I. (1998). Therapeutic interaction. A study of mutual help in Alcoholics Anonymous. The Finnish Foundation of Alcohol Studies.
Baumgartner, L.M. (2001). An update on Transformational Learning. Teoksessa Merriam, S. B, (toim.) The New Update on Adult Learning Theory. Jossey-Bass.

Brookfield, S. (1987). Developing Critical Thinkers. Jossey-Bass.

Cameron, D. 2000. Good to talk? London: Sage.

Edwards, D. 1995. Two to tango: Formulations, dispositions, and rhetorical symmetry in relationship troubles talk. Research on Language and Social Interaction 28 (4), 319-350.

Edwards, R. (1994). 'Are you experienced?': postmodernity and experiential learning. International Journal of Lifelong Learning 13, 6: 423-439.

Ehrling L. (2004). Haastattelijoiden vuorot psykoterapian vaikuttavuuden seurantahaastatteluissa. Julkaisematon käsikirjoitus. Helsingin yliopisto, Sosiaalipsykologian laitos.

Foucault, M. (2005). Seksuaalisuuden historia. Gaudeamus.

Furedi, F. (2004). Therapy Culture.Cultivating vulnerability in an uncertain age. Routledge.

Glastra, F., Hake, B. J. \& Schedler, P.E. (2004). Lifelong learning as transitional learning. Adult Education Quarterly 54(4): 291-307.

Giddens, A. (1991). Modernity and Self-identity. Self and Society in the Late Modern Age. Polity Press.

Have ten, P. (1999). Doing Conversation Analysis. A Practical Guide. Sage.

Heritage, J. (1997). Conversation Analysis and Institutional Talk: Analysing Data. Teoksessa Silverman, D. (toim.): Qualitative Research. Theory, Method and Practice. Sage.

Jarvis, P. (1987). Adult Learning in the Social Context. Croom Helm.

Kivivuori, J. (1991). Psykokulttuuri. Gaudeamus/Hanki ja jää.

Kivivuori, J. (1999). Psykokirkko. Gaudeamus/ Hanki ja jää.

Kovan, J.T. \& Dirkx, J, M. (2003). ’Being called awake: the role of transformative learning in the lives of environmental activists. Adult Education Quarterly 53(2), 99-118.

Knekt, P. \& Lindfors, O. (toim.) (2004). A randomized trial of the effect of four forms of psychotherapy on depressive and anxiety 
disorders. Design, methods, and results on the effectiveness of short-term psychodynamic psychotherapy and solution-focused therapy during a one-year follow-up. The Social Insurance Institution, Finland, Studies in social security and health 77.

Kroth, M. \& Boverie, P. (2000). Life mission and adult learning. Adult Education Quarterly 50 (2), 134-149.

Malinen. A. (2000). Towards the essence of adult experiential learning. SoPhi.

Marsick, V. J. \& Watkins, K. (1990). Informal learning in the workplace. Routledge.

Maynard, D. (2003). Bad news, good news. Conversational order in everyday talk and clinical settings. The University of Chicago Press.

Mezirow, J. (1981). A critical theory of adult learning and education. Adult Education 32, 1.

Mezirow, J. and Associates. (1990). Fostering Critical Reflection in Adulthood. A Guide to Transformative and Emancipatory Learning. Jossey-Bass.

Mäntylä, E. (2003). Kuudesluokkalaisen oppilaan reflektio ja metakognitio itseohjautuvuusvalmiutta harjoittavassa opiskeluprojektissa. Joensuun yliopiston kasvatustieteellisiä julkaisuja 87.

Nikander, P. (2002). Age in Action. Membership work and stage of life categories in talk. The Finnish Academy of Science and Letters. Annales Academiae Scientiarum Fennica, Humaniora 321.

Näre, S. (1999). Sukupuolten tunnekulttuuri ja julkisuuden intimisoituminen. Teoksessa Näre, S. (toim.) Tunteiden sosiologiaa I: Elämyksiä ja läheisyyttä. SKS.

Peräkylä, A. (1995). AIDS counselling. Institutional interaction and clinical practice. Cambridge University Press.

Peräkylä, A. (2004). Making links in psychoanalytic interpretations: a conversation analytic view. Psychotherapy Research 14, 3, 289-307.

Peräkylä, A. and Silverman, D. (1991). Owning experience: Describing the experience of other persons. Text 11 (3), 441-480.

Rogers, C. (1994[1967]). On becoming a person. A therapist's view of psychotherapy. Constable.

Rose, N. (1999). Governing the soul. The shaping of the private self. Free Association Books.
Schön, D. A. 1991(1983). The reflective practitioner : how professionals think in action. Aldershot: Avebury.

Seppänen, E-L. (1997). Vuorovaikutus paperilla. Teoksessa Tainio, L. Keskustelunanalyysin perusteet. Vastapaino.

Tainio, L. (2001a). Feministinen keskustelunanalyysi. Teoksessa Halonen, M. \& Routarinne, S. (toim.) Keskustelunanalyysin näkymiä. Kieli 13. Helsingin yliopiston suomen kielen laitos.

Tainio, L. (2001b). Puhuvan naisen paikka. Sukupuoli kulttuurisena kategoriana kielenkäytössä. SKS.

Taylor, C. (1995). Autenttisuuden etiikka. Gaudeamus.

Tontti, J. (2000). Masennuksen arkea. Selityksiä surusta ilman syytä. Sosiaalipsykologisia tutkimuksia 3. Helsingin yliopiston sosiaalipsykologian laitos.

Usher, R. Bryant, I. \& Johnston, R. (1997). Adult education and the postmodern challenge. Learning beyond the limits. Routledge.

Vehviläinen, S. (2003). Preparing and delivering interpretations in psychoanalytic interaction. TEXT 23, 4, 573-606.

Vehviläinen S. (2004). Tunteet ja vuorovaikutus. Aikuiskasvatus 2, 141-153.

Artikkeli saapui toimitukseen 18.5.2005. Se hyväksyttiin julkaistavaksi toimituskunnan kokouksessa 22.8.2005. 